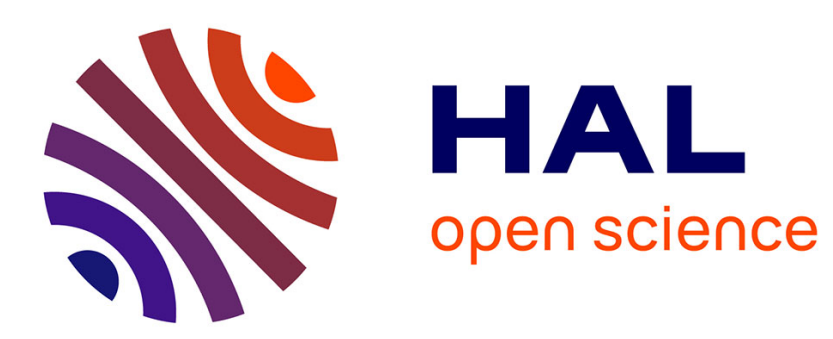

\title{
The Challenge of Evil in Islamic Thought: A Brief Survey
}

\author{
Sajjad Rizvi, Mathieu Terrier
}

\section{To cite this version:}

Sajjad Rizvi, Mathieu Terrier. The Challenge of Evil in Islamic Thought: A Brief Survey. Oriens, 2021, 49 (3-4), pp.173-180. 10.1163/18778372-12340009 . halshs-03502415

\section{HAL Id: halshs-03502415 https://shs.hal.science/halshs-03502415}

Submitted on 5 Jan 2022

HAL is a multi-disciplinary open access archive for the deposit and dissemination of scientific research documents, whether they are published or not. The documents may come from teaching and research institutions in France or abroad, or from public or private research centers.
L'archive ouverte pluridisciplinaire HAL, est destinée au dépôt et à la diffusion de documents scientifiques de niveau recherche, publiés ou non, émanant des établissements d'enseignement et de recherche français ou étrangers, des laboratoires publics ou privés. 
The Challenge of Evil in Islamic Thought: A Brief Survey

Sajjad Rizvi

University of Exeter

s.h.rizvi@exeter.ac.uk

and

Mathieu Terrier

CNRS, PSL, LEM, Paris

met terrier@yahoo.fr

Muslim philosophers and theologians were neither the first group of thinkers - nor indeed the last - to grapple with the challenge of evil to theism and indeed the belief in a morally perfect creator God. The recurrent problem of evil, especially in the modern age of genocides and pandemics, seems to arise from the gap between the visible and apparently ubiquitous presence of evils (even of the most horrendous and radical types) and seeming inadequacy of rational resources to explain and resolve them. The presence of these evils, moral and metaphysical, were very much present to premodern thinkers with wars and famine, and pandemics like the plague and the Black Death. Nevertheless, over the ages, thinkers have presented resolutions, defences and theodicies. In contrast to Mazdaism, Manichaeism and ancient Gnosis, which limit the power of God by a counter-principle in order to exonerate him from any direct causal responsibility for evil, traditional (Abrahamic) monotheisms often place God at the centre of all metaphysics: there can be neither being, meaning, or value without God. On the face of it, the scriptural sources in Islam propose three types of positions: on the existence of God's goodness and justice (Qur'an 3.18, 55.6o and so forth), on God's creative agency with respect to all things including evil (assuming evil is a thing, Qur'an 6.164), but also on the human responsibility of humans for evil that they perform (or at least ascribe to themselves, Qur'an 2.281, 41.46). God's justice is asserted as well as her judgement while denying the possibility for humans to drag God into the court of their judgement. Similarly, divine freedom to act as well as the scope for human free will to action are considered to be rationally compatible.

The presence of evil needs to be squared with God's goodness, her creative agency, and her recompense for human actions. In the modern analytic tradition, this conundrum was restated by Mackie as the incompatibility that arises from three propositions: ${ }^{1}$

1. God is omnipotent

\footnotetext{
${ }^{1}$ J.L. Mackie, 'Evil and omnipotence', Mind 64 (1955): 200-212. His argument always rests upon David Hume's famous formulation in his Dialogues Concerning Natural Religion.
} 
2. God is omnibenevolent

3. (but) some evil exists

Stump extends this to posit a further result that the convergence of these premises entails that there is 'no morally sufficient reason for God to allow instances of evil'. ${ }^{2}$ The presence of evil is thus seen as providing a case for denying the existence of God (the 'evidential argument from evil'), or at the very least of a good and omnipotent one. One can disaggregate the challenge of evil by considering the question of a particular evil (the famous Lisbon earthquake for Leibniz), the amount of evil (why is there so much evil and suffering in the world?) and particular kinds of evil (how can God permit genocide?). All of those have inspired responses. According to Ricoeur, theodicy is the effort to account for these three propositions together, by satisfying the logic of non-contradiction and systematic totalisation, and a discourse which arises after those of myth, prophetic wisdom (Job's book) and gnosis, reflecting an increasing rationality. ${ }^{3}$ It requires a response that brings together a thoughtful reflection, moral agency (struggling against evil), and a spiritual transformation of the affective and affected person. This adequately indicates the importance of the agonistic element of formulating a theodicy which puts the onus back on the human actor. To what extent such theodicies account for and provide a rational solution to the problem is a matter of contestation; certainly, there is a sense that much theodicy constitutes attempts at providing philosophically therapeutic resolutions to the problem, possibly curing the 'disease' of misunderstanding. ${ }^{4}$ At the very least, they tell us more about certain anthropological and indeed theological commitments to one's conception of the nature of God and of the human. ${ }^{5}$ At the therapeutic level, there is a continuity with Ricoeur's insight that we cannot merely wish evil away through the pure exercise of the intellect. Certainly, some quasi-fideist arguments might set aside the adequacy of a thorough and systematic theodicy in favour of a more agnostic capitulation in the search for rationalisations, in the recognition that many of the theodicies fail to convince. ${ }^{6}$ One might even take comfort from the narratives of hagiographies that urge forbearance.

\footnotetext{
2 Elenore Stump, 'The problem of evil', Faith and Philosophy 2.4 (1985): 392-423.

${ }^{3}$ Paul Ricoeur, 'Evil: A Challenge to Philosophy and Theology', Journal of the American Academy of Religion LIII/3 (1985): 635-65o; a short book version was also published: Evil: A Challenge to Philosophy and Theology, tr. John Bowden (London: Continuum, 2007). On an attempt to make sense of the Job narrative and its implications within an inter-cultural and inter-religious (Christian, Muslim, Jewish) philosophical context, see the forthcoming book by Scott Davison, Sajjad Rizvi, and Shira Weiss.

${ }^{4}$ Claire Carlisle and Jonardon Ganeri (ed), Philosophy as Therapeia, Royal Institute of Philosophy Supplements (Cambridge: Cambridge University Press, 2010); James F. Peterman, Philosophy as Therapy (Albany: State University of New York Press, 1992); Martha Nussbaum, The Therapy of Desire: Theory and Practice in Hellenistic Ethics (Princeton: Princeton University Press, 1996).

${ }^{5}$ For example, one thinks of the famous free-will defence articulated by Alvin Plantinga, 'The free-will defence', in Philosophy in America, ed. Max Black (London: Allen and Unwin, 1965), 204-220, and more recently Peter van Inwagen, The Problem of Evil (Oxford: Oxford University Press, 2006).

${ }^{6}$ See William P. Alston, 'Some (temporarily) final thoughts on evidential arguments from evil', in The Evidential Argument from Evil, ed. Daniel Howard-Snyder (Bloomington, IN: Indiana University Press, 1996), 311-32.
} 
However, from the beginning of Islamic theology ( $i l m$ al-kalām) and philosophy up to the present time historically, and in the present time, thinkers of differing persuasions have addressed the incoherence through questioning the validity of one of the premises or by inserting new premises and parallel propositions. While there are anti-theodicies and even disavowals of defences, Islamic intellectual history is replete with the search for reasons. ${ }^{7}$ For example, the Mu'tazila suggested that God's freedom to act was constrained by his own laws of logic and metaphysics; good and evil have real existence, independent from revelation and necessarily known - or at least knowable - by human reason (al-husn wa'l-qubḥ 'aqlīyān); God could therefore not do everything humanly conceivable. ${ }^{8}$ Forms of open theism in recent times have developed the notion that God desires for humans a collaboration in what will be and therefore future contingents are conditional upon human choices and action. ${ }^{9}$ Even in Judaism, Hans Jonas argues, the irreducible existence of evil compels the theologian to strip the concept of God of the attribute of omnipotence in order to conserve his absolute goodness and intelligibility. ${ }^{10}$ Second, the assertion of God's moral goodness could be due to our standards of morality above which God transcends; according to the Ašăira, both good and evil are standards determined by the revealed law (šar); good is what the Lawgiver commands and evil is what He prohibits; therefore, the second premise of rational theodicy may not hold. ${ }^{11}$ Finally, following the Neoplatonists, a number of thinkers in the Islamic traditions - starting especially with Ibn Sīnā as we shall see - both denied that evil existed and consider our notion of 'evil', following Proclus, to be an accidental or incomplete good, whose goodness can only be clear from a divine perspective. Mackie as well as Ricoeur considered most of these solutions, especially those couched in a 'best of all possible worlds' theodicy, according to Leibniz' famous Essays, to be fallacious because they circumvent the problem and fail to tackle them head on. ${ }^{12}$ Other solutions presented forms of solace, comfort and even therapeutic relief: evil was the cost of human free will, on balance the good outweighed the bad, and love of God and God's love for humans would compensate any suffering caused by moral and natural evils.

\footnotetext{
${ }^{7}$ On the former, see Ayman Shihadeh, 'Avicenna's theodicy and al-Rāzì's anti-theodicy', Intellectual History of the Islamicate World 7 (2019): 61-84; Jon Hoover, Ibn Taymiyya's Theodicy of Perpetual Optimism (Leiden: Brill, 2007), 177-210; and Safaruk Chowdhury, Islamic Theology and the Problem of Evil (Cairo: The American University Press, 2021).

${ }^{8}$ See Sophia Vasalou, Moral Agents and their Deserts: The Character of Mu'tazilite Ethics (Princeton: Princeton University Press, 2008). For a useful study of the positions of the Mu'tazila and Ašăcira on human agency and responsibility with respect to moral evils, see Muhammad Āyat Ḥamū, Muškilat al-af'āl al-insānīya bayn al-hualq al-ítizālī wa'l-kasb al-aš arī (Casablanca: al-Markaz altaqāfî al-'arabī, 2015).

${ }^{9}$ See, among others, William Hasker, God, Time, and Knowledge (Ithaca: Cornell University Press, 1998).

${ }^{10}$ Hans Jonas, 'The concept of God after Auschwitz: a Jewish Voice', The Journal of Religion 67/1 (1987): 1-13, and see the discussion in Richard Bernstein, Radical Evil: A Philosophical Interrogation (Cambridge: Polity Press, 2002), 184-204.

${ }^{11}$ Sophia Vasalou, Ibn Taymiyya's Theological Ethics (Oxford: Oxford University Press, 2016), 107-19.

12 On Leibniz's theodicy, see Michael J. Murray, and Sean Greenberg, 'Leibniz on the Problem of Evil', The Stanford Encyclopedia of Philosophy(Winter 2016 Edition), Edward N. Zalta (ed.), URL = https://plato.stanford.edu/archives/winzo16/entries/leibniz-evil/
} 
In this volume, we gather together six studies that address ways in which different Neoplatonic strategies of theodicy for overcoming evil or at least defending God from the charge of evil-doing, most of them in a Shici milieu and often under the influence of Neoplatonism, are developed from the tenth century to modern times, culminating in one more anthropologically oriented article that consider therapeutic performances of the cosmic drama of good and evil in contemporary Shici Islam as one enactment of theodicy. ${ }^{13}$ These are very much explicitly designed as theodicies. It thus illustrates the fruitfulness of the challenge of evil for religious thought in Islam, not only among scholars and philosophers, but also among ordinary believers.

In the first article, Daniel de Smet examines the ways in which the drama of good and evil plays out in Ismaili thought progressing through four 'acts', emphasising the very nature of the cosmic performance and emplotment of ontological and moral value. As is the case with other Shici traditions, Ismailism developed a dualistic worldview ruled by the opposition between good and evil, light and darkness. However, it is a rather moderate form of dualism, as the principle of evil is not coexistent with the Creator or has not been created by Him. The friends of God who represent the light and the good are few in number and are denied in the historical contingency of the drama. The first act offers a gnostic thesis where evil is the result of a rebellion in the intelligible world. The second act shifts to the Neoplatonic thesis where evil and imperfection are caused by the process of emanation itself. The third outlines a philosophical thesis where the generation of evil by "second intention" belongs to the rule of divine providence. Finally, in the fourth act, in their Eastern exile, the Țayyibi authors of the $12^{\text {th }}$ century produce a synthesis of the previous three positions. As such we see a number of Ismaili theodicies at play and the article demonstrates the diversity even within one theological branch of Islamic thought on this particular issue.

We then move onto the most influential thinker on divine providence in Islamic thought and perhaps the archetypal philosopher, Abū 'Alī al-Ḥusayn b. 'Abd Allāh Ibn Sīnā (d. 1037), known as Avicenna in the Latin West. Meryem Sebti examines the role of evils within his moral and political thought. The question of evil poses an acute problem within Avicenna's doctrine of the soul. How can the human soul, which is an unalterable spiritual substance, be affected by the evil committed? Answering this question requires the study of Avicenna's eschatology as well as the study of the status of ethical norms. The latter, according to Avicenna, are not universal and therefore not accessible to the intellect but are given by revelation. The question of moral evil in Avicenna cannot be understood without placing it in the metaphysical and ethical

\footnotetext{
${ }^{13}$ These articles are taken from lectures given at the symposium 'The Problem of Evil: a Challenge to Shi'i Theology and Philosophy in Islam', organised by Patrizia Spallino (OSM, Palermo) and Mathieu Terrier (CNRS, Paris) in Palermo, Officina di Studi Medievali, on 26-28 October 2016, with the support of the CNRS International Research Group (GDRI) 'New Horizons for the Social and Intellectual History of Shi' ism in Modern Times' directed by Denis Hermann (CNRS).
} 
system of the Persian philosopher. Importantly, this problem demonstrates some of the limitations of a purely 'philosophical' approach to his thought and contributes to the growing sense that we need to think carefully about the category of 'philosophy' in the Islamic world and the relationship between the syllogistic, the demonstrative and other forms of persuasive and certainty-yielding arguments.

Jari Kaukua's contribution turns to one of the most influential critics of Avicennism in the vibrant $12^{\text {th }}$ century, Šihāb al-Dīn Yahyā b. Ḥabaš al-Suhrawardī al-maqtūl (d. 1191). His philosophical works seem to contain two conflicting views on providence and evil: in the Talwịhăt and the Mašăric he seems to endorse the Avicennian view, only to deny providence altogether in his later and definitive work Hikmatal-išrāq. This contribution aims to explain the seeming inconsistency by investigating it in light of the underlying question of God's knowledge of particular things. Kaukua also argues that despite his qualms concerning providence, Suhrawardī accepts the closely related Avicennian answer to the question of evil. To an extent, the seeming contradiction is often found on a number of other issues on which Suhrawardī responds to Avicenna. A focus on God's knowledge of particulars reminds us of the basic ontology of the illuminationist thinkers in which it is only particular bodies that exist and which brings to mind the nominalist commitments of his metaphysics.

From the beginnings of Avicennian positions on evil and their critique, we shift to later Safavid period analyses of evil within the context of contested readings of Avicenna and of the revival of Neoplatonism. Mathieu Terrier discusses the thought of Mīr Muhammad Bāqir Dāmād Astarābādī (d. 1631) and his students Mullā Šamsā Gīlānī (d. 1654), in a brief epistle on perfection, and Quṭb al-Dīn Aškivarī (d. between 1677 and 1684), in his monumental history of universal wisdom. The problem of the goodness of God, the freedom of the human and the origin of evil, namely, theodicy, proves to be particularly acute in Twelver Shici Islam, because of the historical awareness of evil and suffering within the community and of the fundamental dualism, metaphysical as well as moral, of the doctrine. Terrier examines the way in which Mīr Dāmād deals successively with the problem of human freedom (qadar) versus divine determinism (ğabr), with the Shici notion of badā', that is, the apparent change of the divine Will in the course of history, with Good and Evil with regards to the ontological categories of essence ( $\underline{d a} t)$, accident ('araḍ), existence (wuğūd), and nonexistence ('adam), and with the execution of eschatological threats and the punishment of the damned thus embracing all the dimensions of the problem and phenomenon of evil; and how his students developed some of his solutions. Terrier concludes that the problem of evil was a powerful catalyst for the emergence of a "Shici philosophy" in the $11^{\text {th }} / 17^{\text {th }}$ century in which its role must be considered alongside a particular vision of history and presence. 
Sajjad Rizvi then analyses the thought of Mīr Dāmād's most famous student, Mullā Șadrā Šīrāzī (d. 1636). He examines the problem of evil and theodicy through an analysis of a section of the theology (al-ilāhìyāt bi'lma'nā al-ahaș̣s or metaphysica specialis in the parlance of the later tradition) in al-Asfär al-arba'a (The Four Journeys) of Mullā Șadrā (mawqif VIII of safar III) and juxtaposes it with passages from his other works, all the while contextualising it within the longer Neoplatonic tradition of providence and evil. The text makes it clear the extent of Mullā Șadrā's debt on the question of divine providence to previous thinkers, namely Avicenna (d. 1037, al-Šifầ’ and Risālat al-išqu) al-Ġazālì (d. 1111, Iḥyā’ 'ulūm al-dīn), and Ibn 'Arabī (d. 1240, alFutūhăăt al-makkīya). What emerges, however, is an account of providence that is subservient to Mullā Șadrā's wider ontological commitment to the primary reality of being, its modulation and essential motion - the tripartite doctrines of așālat al-wuğūd (ontological primacy of existence), taškikk al-wuğūud (modulation of existence) and al-haraka al-ğawharìya (motion in the category of substance) - and fits within his overall approach to the procession of the cosmos from the One as a divine theophany and its reversion back to the One through theosis. Thus, an analysis of providence and evil demonstrates that underlying significance of Mullā Ṣadrā's metaphysical commitments to a modulated monism.

The final article takes us from the formal inscription of philosophical treatises to the performative stage of the drama of good and evil. Sepideh Parsapajouh analyses the ways in which the celebration of the carnivalesque, of the suffering of the good, and the defeat of evil are enacted in modern Iranian Twelver Shi $i$ Islam. There, two categories of popular traditions (including rituals, practices and beliefs) have taken shape over time around the issue of evil, namely the harm and death suffered by the holy figures of the house of the Prophet (ahl al-bayt). The first category includes elegiac poetic expressions (marsinyeh), accompanied by ritual practices reflecting passion and compassion for the victims of unjust death - notably the third imam, al-Husayn b. 'Alī. The second category includes violent and satirical expressions of maledictions, addressed to the authors of this evil. This tradition also involves the recitation of prayers and devotional formulas borrowed from the sacred scriptural corpus as well as particular practices called 'Umar-košl (the murder of Umar). Parsapajouh offers an analysis of the formation and function of these two traditions, as well as the development of their form and meaning in the social context of contemporary Iranian Shi'i Islam. It shows that, by being in line with the double Shici principle of tawalla (loyalty and love towards the Imams - love for the good and for justice) and tabarrā (dissociation and hatred towards the enemies of the Imams dissociation from evil and suffering), these two traditions clearly reflect the autonomy of the believers vis-àvis both political power and institutional religious authority. As such it attunes us to the idea that the 
discussion of good and evil cannot be divorced from that of power and sometimes ought to disabuse us of the notion that evil and indeed power are absolutes. ${ }^{14}$

${ }^{14}$ See, for example, the recent work of Simona Forti, New Demons: Rethinking Power and Evil Today, tr. Zakiya Hanafi (Stanford: Stanford University Press, 2014). 